\title{
Structural and Physical Properties of ZnO Modified Bismuth Silicate Glasses
}

\author{
J. Hooda, R. Punia, R. S. Kundu, Sunil Dhankhar, and N. Kishore \\ Department of Applied Physics, Guru Jambheshwar University of Science and Technology, Hisar 125001, India \\ Correspondence should be addressed to R. S. Kundu, rskundu2007@gmail.com
}

Received 19 October 2012; Accepted 27 November 2012

Academic Editors: A. Cricenti and J. H. Z. Dos Santos

Copyright () 2012 J. Hooda et al. This is an open access article distributed under the Creative Commons Attribution License, which permits unrestricted use, distribution, and reproduction in any medium, provided the original work is properly cited.

Zinc bismuth silicate glasses with compositions $40 \mathrm{SiO}_{2} \cdot x \mathrm{ZnO} \cdot(60-x) \mathrm{Bi}_{2} \mathrm{O}_{3}(x=0,5,10,15,20,25,30,35$, and 40$)$ have been prepared by conventional melt-quench technique and the solubility limit of zinc in bismuth silicate glass system has been estimated using X-ray diffraction technique. Density has been measured using Archimedes' principle; with increase in $\mathrm{ZnO}$ in the samples, the molar volume and density are found to decrease. The glass transition temperature $\left(T_{g}\right)$ has been determined by using differential scanning calorimetry (DSC) and is observed to increase with increase in ZnO content. Raman and FTIR spectra have been recorded at room temperature and the analysis of Raman and FTIR shows that in all the glass compositions, asymmetric and symmetric stretched vibrations of $\mathrm{Si}-\mathrm{O}$ bonds in $\mathrm{SiO}_{4}$ tetrahedral units exist and with decrease in $\mathrm{Bi}_{2} \mathrm{O}_{3}$, the contribution of symmetric vibrations begins to dominate which results in increased compactness of the glass structure.

\section{Introduction}

Glasses based on heavy metal oxide have attracted attention of researcher's community for their excellent IR transmission compared with conventional glasses $[1,2]$. The bismuth oxide glasses have wide range of applications for optical and electronic devices, mechanical sensors, and reflecting windows $[3,4] . \mathrm{Bi}_{2} \mathrm{O}_{3}$ is not a classical glass former but due to high polarisibility and small field strength of $\mathrm{Bi}^{3+}$ ions, in the presence of conventional glass formers like $\mathrm{SiO}_{2}$, $\mathrm{PbO}$ and $\mathrm{B}_{2} \mathrm{O}_{3}$, a glass network of $\mathrm{BiO}_{3}$ and $\mathrm{BiO}_{6}$ may be built [5]. However, the structural role played by $\mathrm{Bi}_{2} \mathrm{O}_{3}$ in glasses is complicated. $\mathrm{Bi}_{2} \mathrm{O}_{3}$ is suitable for forming glass with high refractive index, nontoxicity, wide transmission range, and so forth [6]. $\mathrm{SiO}_{2}$ in its various amorphous forms has an extremely wide spectrum of industrial applications [7]. Several reports on $\mathrm{ZnO}-\mathrm{Bi}_{2} \mathrm{O}_{3}$ with $\mathrm{B}_{2} \mathrm{O}_{3}$ and $\mathrm{TeO}_{2}$, $\mathrm{CdO}-\mathrm{ZnO}-\mathrm{V}_{2} \mathrm{O}_{5}, \mathrm{~V}_{2} \mathrm{O}_{5}-\mathrm{Bi}_{2} \mathrm{O}_{3}-\mathrm{B}_{2} \mathrm{O}_{3}$, and $\mathrm{V}_{2} \mathrm{O}_{5}-\mathrm{ZnO}-\mathrm{Bi}_{2} \mathrm{O}_{3}$ systems exist in literature [8-14], but physical and structural studies of $\mathrm{SiO}_{2}-\mathrm{ZnO}-\mathrm{Bi}_{2} \mathrm{O}_{3}$ are rare.

The aim of present paper is to investigate the effect of $\mathrm{ZnO}$ on physical and structural properties of bismuth silicate glass samples using the techniques of XRD, DSC, FTIR, and Raman spectroscopy.

\section{Experimental}

The glass samples in the system $40 \mathrm{SiO}_{2} \cdot x \mathrm{ZnO} \cdot(60-$ $x) \mathrm{Bi}_{2} \mathrm{O}_{3}$ with composition $x=0,5,10,15,20,25,30,35$, and 40 were prepared using analar grade $\mathrm{SiO}_{2}, \mathrm{Bi}_{2} \mathrm{O}_{3}$, and $\mathrm{ZnO}$ chemicals, by conventional melt-quench method. However, the samples with $x$ ( $\mathrm{ZnO}$ content) higher than 40 had also been tried to synthesize but we could not succeed. For the synthesis of samples, the weighed quantities of $\mathrm{SiO}_{2}$, $\mathrm{ZnO}$ and $\mathrm{Bi}_{2} \mathrm{O}_{3}$ in appropriate proportions were well-mixed using pestle mortar and then the mixture was taken in silica crucible. The crucible containing mixture was then put in an electrically heated muffle furnace and temperature was slowly raised to $1100^{\circ} \mathrm{C}$ at which the mixture gets melted. The melt was kept at $1100^{\circ} \mathrm{C}$ for half an hour and was shaken for proper mixing and homogeneity. The coin shaped glass samples were obtained by pouring and quenching the melt in between two stainless steel plates at room temperature. Density of glass samples was measured using Archimedes' Principle with water as buoyant liquid. X-ray diffraction patterns were taken by using Rigaku Table Top X-ray Diffract meter (XRD) to detect the amorphous character. The glass transition temperature $\left(T_{g}\right)$ was determined from differential scanning calorimetry (DSC) using TA instruments, Model 


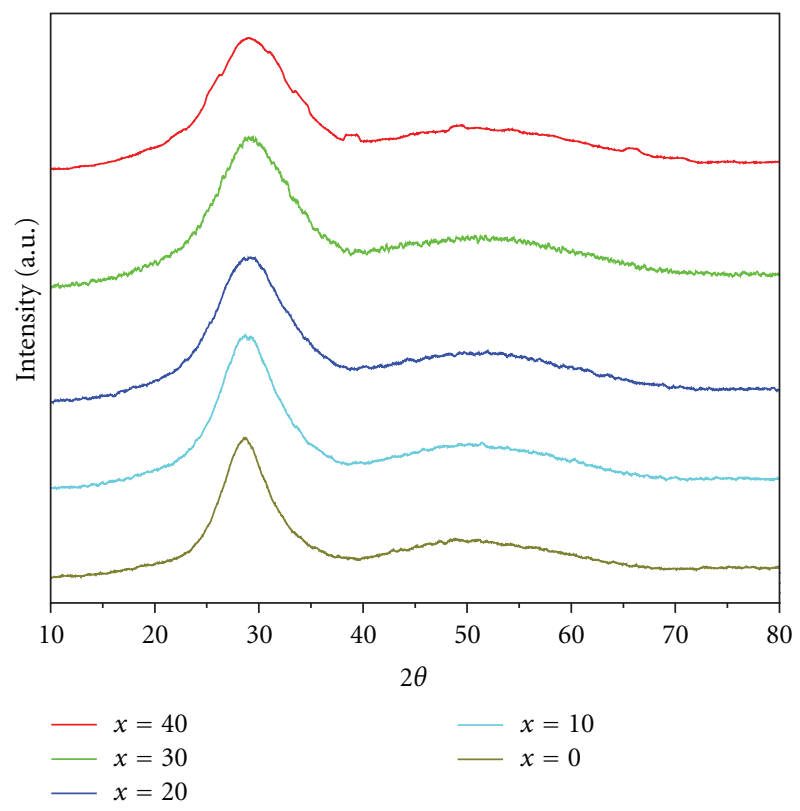

Figure 1: XRD of different $40 \mathrm{SiO}_{2} \cdot x \mathrm{ZnO} \cdot(60-x) \mathrm{Bi}_{2} \mathrm{O}_{3}$ glass compositions.

No. Q600 SDT. For this purpose glass samples were heated in nitrogen atmosphere at rate of $20^{\circ} \mathrm{C} / \mathrm{min}$ in the temperature range of $40^{\circ} \mathrm{C}$ to $1000^{\circ} \mathrm{C}$. Infrared transmission spectra were recorded at room temperature using Shimadzu FRIT$8001 \mathrm{PC}$ spectrometer over the range 400 to $2000 \mathrm{~cm}^{-1}$. The powdered samples were thoroughly mixed with dry $\mathrm{KBr}$ in ratio of $1: 20$ by weight and then pallets were prepared under pressure of 8-9 tons. The Raman Spectra were recorded using Renishaw Invia Reflex Micro Raman Spectrometer with Ar ion laser (514 nm) under back scattering configuration.

\section{Results and Discussion}

The prepared glass samples of $40 \mathrm{SiO}_{2} \cdot x \mathrm{ZnO} \cdot(60-x) \mathrm{Bi}_{2} \mathrm{O}_{3}$ with $x=0,5,10,15,20,25,30,35$, and 40 were found to be light yellow in colour. The XRD patterns of glass samples with $x=0,10,20,30$, and 40 are shown in Figure 1 . The presence of broad spectrum and absence of any sharp peak in X-ray diffractograms confirms amorphous nature of the synthesized glass samples. The measured values of density $(\rho)$ for all samples are given in Table 1. Perusal of the data presented in Table 1 reveals that the density of samples decreases with increase in $\mathrm{ZnO}$ content. This is usual trend as heavier $\mathrm{Bi}_{2} \mathrm{O}_{3}$ molecules are replaced by lighter $\mathrm{ZnO}$ molecules.

The molar volume $\left(V_{m}\right)$ was calculated by using the relation

$$
V_{m}=\frac{\sum x_{i} M_{i}}{\rho}
$$

where $\rho$ is density, $x_{i}$, and $M_{i}$ represent the molar fraction and molecular weight of $i$ th component, and density, respectively. The values of $V_{m}$ are also presented in Table 1 and its
TABLE 1: Density $(\rho)$, molar volume $\left(V_{m}\right)$, and glass transition temperature $\left(T_{g}\right)$ of $40 \mathrm{SiO}_{2} \cdot x \mathrm{ZnO} \cdot(60-x) \mathrm{Bi}_{2} \mathrm{O}_{3}$ glasses with different values of $x$.

\begin{tabular}{lccc}
\hline Compositions $(x)$ & $\rho(\mathrm{g} / \mathrm{cc})$ & $V_{m}(\mathrm{cc} / \mathrm{mole})$ & $T_{g}\left({ }^{\circ} \mathrm{C}\right)$ \\
\hline 0 & 6.73 & 45.11 & 451 \\
5 & 6.60 & 43.08 & 471.85 \\
10 & 6.4948 & 40.82 & 459.52 \\
15 & 6.401 & 38.41 & 474 \\
20 & 6.198 & 36.57 & 474 \\
25 & 5.938 & 34.93 & 494 \\
30 & 5.627 & 33.45 & 513 \\
35 & 5.529 & 30.56 & 521 \\
40 & 5.463 & 28.87 & 522 \\
\hline
\end{tabular}

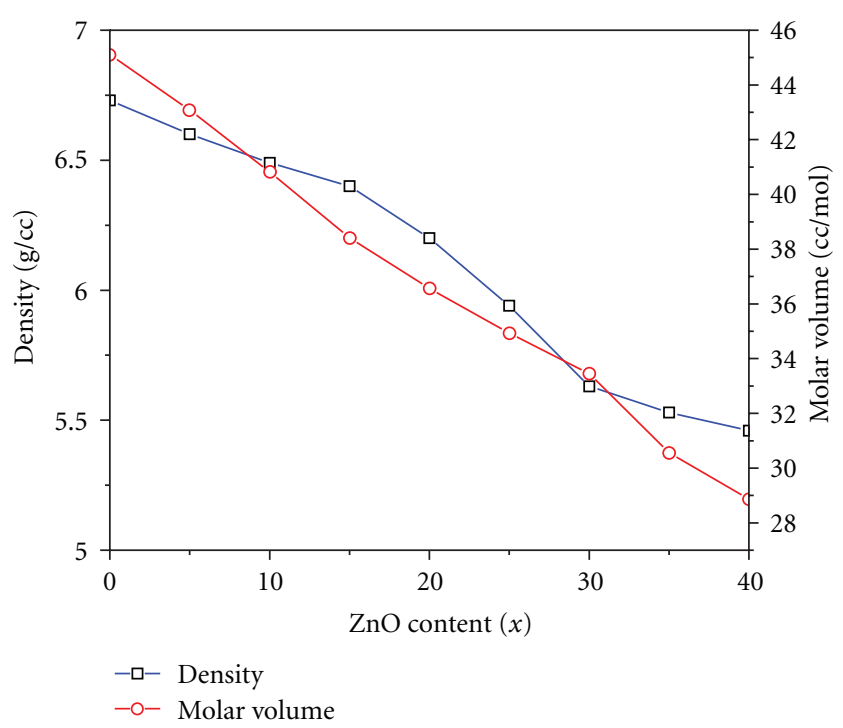

Figure 2: Compositional dependence of density $(\rho)$ and molar volume $\left(V_{m}\right)$ for $40 \mathrm{SiO}_{2} \cdot x \mathrm{ZnO} \cdot(60-x) \mathrm{Bi}_{2} \mathrm{O}_{3}$ glasses.

variation with composition is shown in Figure 2. Perusal of Figure 2 shows that the molar volume also decreases with increase in $\mathrm{ZnO}$ content. Similar results have been reported in the literature for $\mathrm{V}_{2} \mathrm{O}_{5}-\mathrm{Bi}_{2} \mathrm{O}_{3}-\mathrm{ZnO}$ [9] and $\mathrm{Li}_{2} \mathrm{O}-\mathrm{Bi}_{2} \mathrm{O}_{3}$ $\mathrm{ZnO}$ [15] glass systems. The results of differential scanning calorimetry (DSC) for $40 \mathrm{SiO}_{2}-x \mathrm{ZnO}-(60-x) \mathrm{Bi}_{2} \mathrm{O}_{3}$ with $x=$ $0,5,10,15,20,25,30,35,40$ are shown in Figure 3 . The glass forming tendency and thermal stability of glasses may be determined from values of $T_{g}$. It is observed that $T_{g}$ increases with increase in $\mathrm{ZnO}$ content, indicating the increase in glass thermal stability. A decrease of $T_{g}$ associated with an increase in heavy metal oxide content in glassy matrix can be attributed to a network opening [16]. So, network compactness of glassy matrix in the present glass system increases with increases of $\mathrm{ZnO}$ content.

The glass forming tendency and thermal stability of glasses may be determined from values of $T_{g}$. It is observed that $T_{g}$ increases with increase in $\mathrm{ZnO}$ content, indicating the increase in glass thermal stability. A decrease of $T_{g}$ associated with an increase in heavy metal oxide content in glassy matrix 


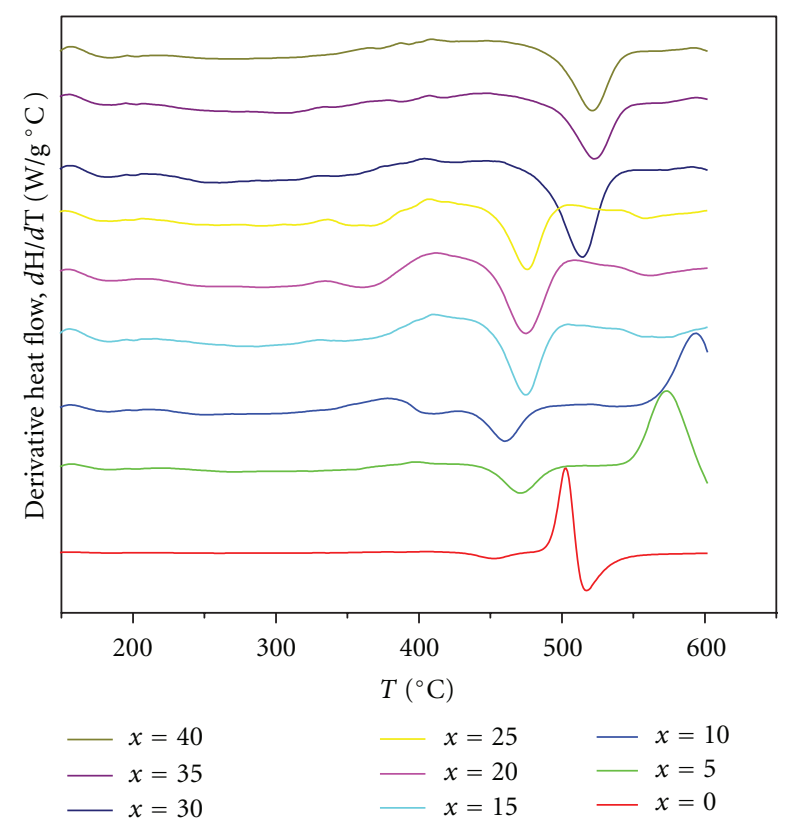

FIGURE 3: Differential scanning calorimetry (DSC) curves for glass system $40 \mathrm{SiO}_{2} \cdot x \mathrm{ZnO} \cdot(60-x) \mathrm{Bi}_{2} \mathrm{O}_{3}$.

can be attributed to a network opening [16]. So, network compactness of glassy matrix in the present glass system increases with incresase of $\mathrm{ZnO}$ content.

The Raman spectra are characterized by three major bands, $\sim 120 \mathrm{~cm}^{-1}, 400 \mathrm{~cm}^{-1}$, and a weak broad band $\sim$ $900 \mathrm{~cm}^{-1}$, for all compositions of $40 \mathrm{SiO}_{2} \cdot x \mathrm{ZnO} \cdot(60-$ $x) \mathrm{Bi}_{2} \mathrm{O}_{3}$ (shown in Figure 4). The FTIR spectra is characterized by two sharp absorption bands between 425 to $550 \mathrm{~cm}^{-1}$ (centred at around $475 \mathrm{~cm}^{-1}$ ), 800 to $1200 \mathrm{~cm}^{-1}$ (centred at nearly $\left.950 \mathrm{~cm}^{-1}\right)$, a small band or flattening at $720 \mathrm{~cm}^{-1}$ in all studied glass samples and a small band occurs around $800 \mathrm{~cm}^{-1}$ in glass samples for $x=25,30,35$, and 40 as shown in Figure 5. In Raman spectra, the band between 50 and $200 \mathrm{~cm}^{-1}$ (centered at around $120 \mathrm{~cm}^{-1}$ ) is usually related to vibrations involving motions of the $\mathrm{Bi}^{3+}$ cations in $\left[\mathrm{BiO}_{6}\right]$ and/or $\left[\mathrm{BiO}_{3}\right]$ units $[17,18]$. Another band centred at $400 \mathrm{~cm}^{-1}$ may be attributed to the $\mathrm{Bi}-\mathrm{O}-\mathrm{Bi}$ and $\mathrm{Bi}-\mathrm{O}$ stretching vibrations of $\mathrm{BiO}_{6}$ Octahedral units $[19,20]$ and may be due to asymmetric bending vibrations of $\mathrm{Si}-\mathrm{O}-\mathrm{Si}$ in $\mathrm{SiO}_{4}$ structural units $[21,22]$.

The intensity of this band decreases with the decrease in $\mathrm{Bi}_{2} \mathrm{O}_{3}$ content in present glass system, suggesting the presence of bismuth as network modifier in the form of $\mathrm{BiO}_{6}$ octahedral units. This is also supported by the FTIR data. In FTIR the bands between 425 to $550 \mathrm{~cm}^{-1}$ and 800 to $1200 \mathrm{~cm}^{-1}$ are attributed to $\mathrm{Bi}-\mathrm{O}-\mathrm{Bi}$ and $\mathrm{Bi}-\mathrm{O}$ Vibrations of $\mathrm{BiO}_{6}$ octahedra $[17,20,23]$. Ardelean et al. [24] has reported a band at $715 \mathrm{~cm}^{-1}$ due to symmetric stretching vibrations of $\mathrm{Bi}-\mathrm{O}$ bond in $\mathrm{BiO}_{3}$ pyramidal units. So, the small kink observed at $720 \mathrm{~cm}^{-1}$ in all the glass compositions may be attributed to symmetric stretching vibrations of $\mathrm{Bi}-$ $\mathrm{O}$ bond in $\mathrm{BiO}_{3}$ pyramidal units. The Raman spectra of all compositions show a weak band around $920 \mathrm{~cm}^{-1}$, which

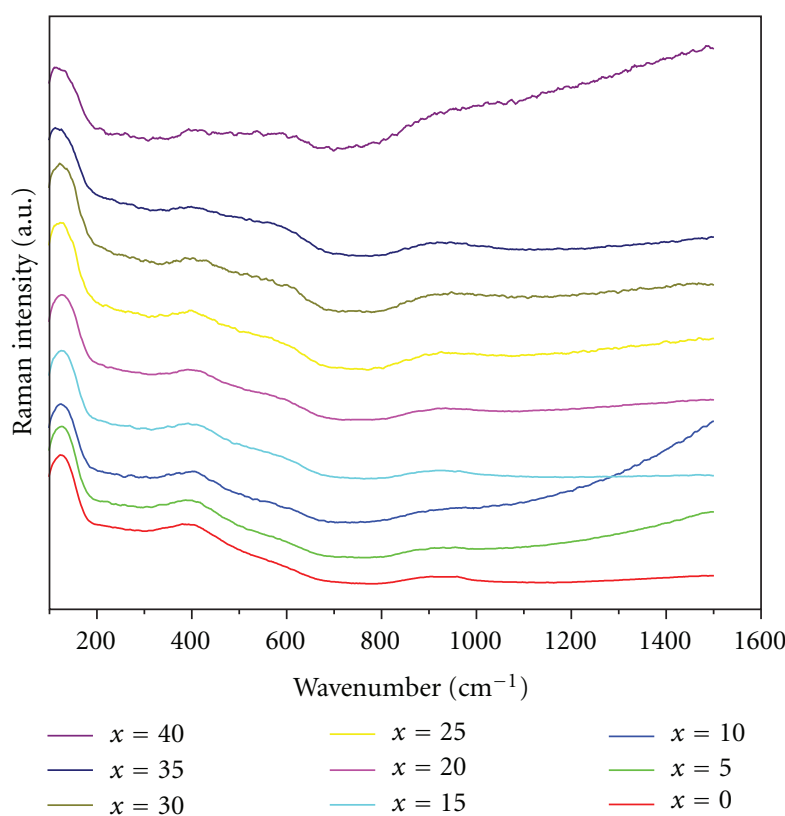

FIGURE 4: Raman spectra for different $40 \mathrm{SiO}_{2} \cdot x \mathrm{ZnO} \cdot(60-x) \mathrm{Bi}_{2} \mathrm{O}_{3}$ glass compositions at room temperature.

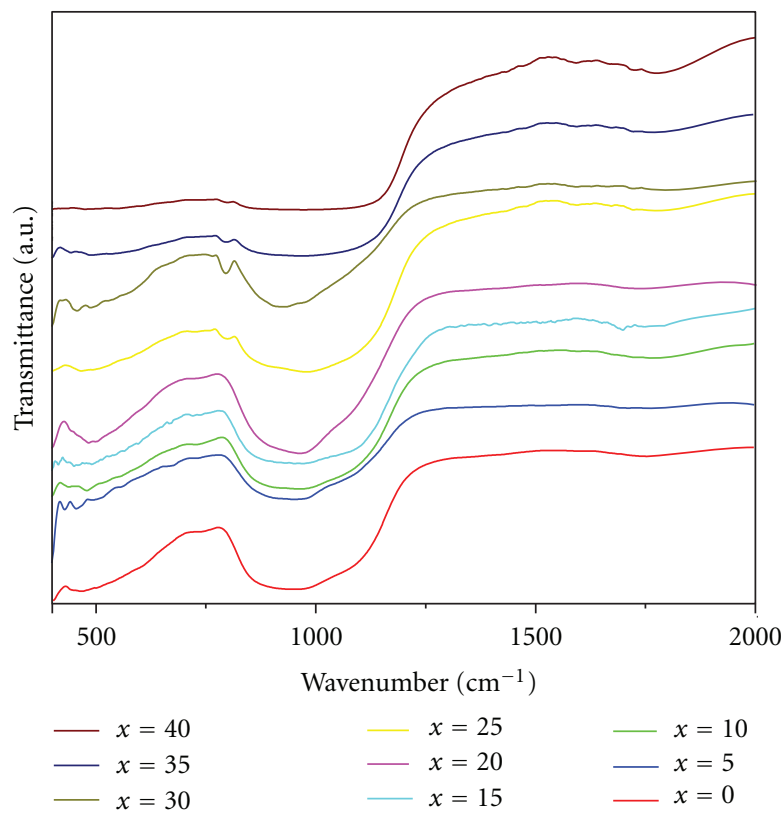

FIGURE 5: Infrared spectra for different $40 \mathrm{SiO}_{2} \cdot x \mathrm{ZnO} \cdot(60-x) \mathrm{Bi}_{2} \mathrm{O}_{3}$ glass compositions at room temperature.

may be attributed to the symmetric stretching vibrations of $\mathrm{SiO}_{4}$ with three non-bridging oxygens [21]. The position and intensity of this band remains same on wave number scale as per our expectations, as the $\mathrm{SiO}_{2}$ content remain same in all the compositions. It is also supported by the FTIR, where band between 800 to $1200 \mathrm{~cm}^{-1}$ is attributed to the asymmetric stretching vibration mode of $\mathrm{SiO}_{4}$ tetrahedra [17]. A small but well-distinguished IR band at around $800 \mathrm{~cm}^{-1}$ is 
present in glass samples with $x=25,30,35$, and 40 . This band is merged in the broad IR band from $800 \mathrm{~cm}^{-1}$ to $1200 \mathrm{~cm}^{-1}$ for other glass compositions. The band at around the $800 \mathrm{~cm}^{-1}$ in FTIR data is attributed to $\mathrm{Si}-\mathrm{O}$ symmetric stretched vibrations [25]. The study of Raman and FTIR spectra shows that in all the glass compositions, asymmetric and symmetric stretched vibrations of $\mathrm{SiO}_{4}$ exist and with decrease of $\mathrm{Bi}_{2} \mathrm{O}_{3}$, the contribution of symmetric vibrations begins to dominate. This may be due to replacement of larger $\mathrm{Bi}_{2} \mathrm{O}_{3}$ molecule by smaller $\mathrm{ZnO}$ molecule and hence may result in decrease of stretching of silicate network. This may result in the increased compactness of the glass structure, which is also evidenced by decrease in molar volume and increase in $T_{g}$. Low frequency band present in FTIR data at around $450 \mathrm{~cm}^{-1}$ in all glass samples is assigned to vibrations of $\mathrm{Zn}^{2+}$ metal cations [9]. The width of the Raman bands in disordered materials is a measure of the disorder in the local structure [26]. The Raman band width decreases with decrease in bismuth content indicating that the vicinity of bismuth in the present glass system is more distorted.

\section{Conclusions}

Various investigations like $\mathrm{X}$-ray diffraction, density, and DSC carried out on $40 \mathrm{SiO}_{2} \cdot x \mathrm{ZnO} \cdot(60-x) \mathrm{Bi}_{2} \mathrm{O}_{3}$ for $x=$ $0,5,10,15,20,25,30,35,40$, and 45 reveal that stable glasses are obtained for $x=0$ to 40 ; the glass forming tendency and thermal stability of these glasses increase with increase in $\mathrm{ZnO}$ content. For higher concentration of $\mathrm{ZnO}$ that is, more than $x=40$, glass formation becomes difficult in the present physical conditions and this may be taken as the solubility limit of $\mathrm{ZnO}$ in present glass system. The density of these glasses is observed to decrease with increase in $\mathrm{ZnO}$ content. On addition of $\mathrm{ZnO}$ into bismuth silicate system, contribution of symmetric vibrations of $\mathrm{Si}-\mathrm{O}$ bonds in $\mathrm{SiO}_{4}$ tetrahedral units dominate over asymmetric vibrations. $\mathrm{Bi}_{2} \mathrm{O}_{3}$ plays the role of both glass former as well as modifier in the present system of study.

\section{Acknowledgments}

The authors are very thankful to DRDO, New Delhi; DST (FIST), New Delhi, for financial assistance in the form of Grants. Two of the authors (R. Punia and J. Hooda) are specially thankful to UGC, New Delhi, for granting the teacher fellowships under Faculty Improvement Programme.

\section{References}

[1] Y. Fujimoto and M. Nakatsuka, "Infrared luminescence from bismuth-doped silica glass," Japanese Journal of Applied Physics, vol. 40, pp. L279-L281, 2001.

[2] X. G. Meng, J. R. Qiu, M. Y. Peng et al., "Near infrared broadband emission of bismuth-doped aluminophosphate glass," Optics Express, vol. 13, no. 5, pp. 1628-1634, 2005.

[3] I. Oprea, H. Hesse, and K. Betzler, "Optical properties of bismuth borate glasses," Optical Materials, vol. 26, no. 3, pp. 235-237, 2004.
[4] M. Łaczka, L. Stoch, and J. Górecki, "Bismuth-containing glasses as materials for optoelectronics," Journal of Alloys and Compounds, vol. 186, no. 2, pp. 279-291, 1992.

[5] Y. Zhang and T. Guo, "Study on the sealing glass of lower melting point in system $\mathrm{Li}_{2} \mathrm{O}-\mathrm{ZnO}-\mathrm{SiO}_{2}$," Vacuum Electronics, vol. 2, pp. 43-45, 2006.

[6] Y. Zhang, Y. Yang, J. Zheng, W. Hua, and G. Chen, "Effects of oxidizing additives on optical properties of $\mathrm{Bi}_{2} \mathrm{O}_{3}-\mathrm{B}_{2} \mathrm{O}_{3}-\mathrm{SiO}_{2}$ glasses," Journal of American Ceramic Society, vol. 91, no. 10, pp. 3410-3412, 2008.

[7] G. H. Beall, "Design and properties of glass-ceramics," Annual Review of Materials Science, vol. 22, no. 1, pp. 91-119, 1992.

[8] L. Baia, R. Stefan, W. Kiefer, and S. Simon, "Structural of characteristics of $\mathrm{B}_{2} \mathrm{O}_{3}-\mathrm{Bi}_{2} \mathrm{O}_{3}$ glasses with high transition metal oxide content," Journal of Raman Spectroscopy, vol. 36, no. 3, pp. 262-266, 2005.

[9] R. Punia, R. S. Kundu, J. Hooda, S. Dhankhar, S. Dahiya, and N. Kishore, "Effect of $\mathrm{Bi}_{2} \mathrm{O}_{3}$ on structural, optical, and other physical properties of semiconducting zinc vanadate glasses," Journal of Applied Physics, vol. 110, no. 3, Article ID 033527, 6 pages, 2011.

[10] D. Saritha, Y. Markandeya, M. Salagram, M. Vithal, A. K. Singh, and G. Bhikshamaiah, "Effect of $\mathrm{Bi}_{2} \mathrm{O}_{3}$ on physical, optical and structural studies of $\mathrm{ZnO}-\mathrm{Bi}_{2} \mathrm{O}_{3}-\mathrm{B}_{2} \mathrm{O}_{3}$ glasses," Journal of Non-Crystalline Solids, vol. 354, no. 52-54, pp. 5573-5579, 2008.

[11] H. Doweidar and Y. B. Saddeek, "FTIR and ultrasonic investigations on modified bismuth borate glasses," Journal of Non-Crystalline Solids, vol. 355, no. 6, pp. 348-354, 2009.

[12] J. Ozdanova, H. Ticha, and L. Ticky, "Remark on the optical gap in $\mathrm{ZnO}-\mathrm{Bi}_{2} \mathrm{O}_{3}-\mathrm{TeO}_{2}$ glasses," Journal of Non-Crystalline Solids, vol. 353, no. 29, pp. 2799-2802, 2007.

[13] G. López-Calzada, M. E. Zayas, M. Ceron-Rivera et al., "Optical characterization of novel matrix glasses based on a CdO: $\mathrm{ZnO}: \mathrm{V}_{2} \mathrm{O}_{5}$ ternary system," Journal of Non-Crystalline Solids, vol. 356, no. 6-8, pp. 374-377, 2010.

[14] C. Tripon, D. Toloman, M. Aluas, C. Filip, and I. Ardelean, "Structural investigation of the $\mathrm{xV}_{2} \mathrm{O}_{5}(1-\mathrm{x})\left[\mathrm{Bi}_{2} \mathrm{O}_{3} \cdot \mathrm{B}_{2} \mathrm{O}_{3}\right]$ glasses by IR absorbtion, EPR and NMR," Journal of Optoelectronics and Advanced Materials, vol. 8, no. 3, pp. 1129-1131, 2006.

[15] S. Bale and S. Rahman, "Glass structure and transport properties of $\mathrm{Li}_{2} \mathrm{O}$ containing zinc bismuthate glasses," Optical Materials, vol. 31, no. 2, pp. 333-337, 2008.

[16] V. C. S. Reynoso, L. C. Barbosa, O. L. Alves, N. Aranha, and C. L. Cesar, "Preparation and characterization of heavymetal oxide glasses: $\mathrm{Bi}_{2} \mathrm{O}_{3}-\mathrm{PbO}-\mathrm{GeO}_{2}-\mathrm{B}_{2} \mathrm{O}_{3}$ system," Journal of Materials Chemistry, vol. 4, no. 4, pp. 529-532, 1994.

[17] C. A. Geiger, "A powder infrared spectroscopic investigation of garnet binaries in the system $\mathrm{Mg}_{3} \mathrm{Al}_{2} \mathrm{Si}_{3} \mathrm{O}_{12}-\mathrm{Fe}_{3} \mathrm{Al}_{2} \mathrm{Si}_{3} \mathrm{O}_{12}-$ $\mathrm{Mn}_{3} \mathrm{Al}_{2} \mathrm{Si}_{3} \mathrm{O}_{12}-\mathrm{Ca}_{3} \mathrm{Al}_{2} \mathrm{Si}_{3} \mathrm{O}_{12}$," European Journal of Minerals, vol. 10, pp. 407-422, 1998.

[18] A. Ghosh, S. Bhattacharya, and A. Ghosh, "Optical and other physical properties of semiconducting cadmium vanadate glasses," Journal of Applied Physics, vol. 101, no. 8, Article ID 083511, 4 pages, 2007.

[19] L. Baia, R. Stefan, J. Popp, S. Simon, and W. Kiefer, "Structural investigations of copper doped $\mathrm{B}_{2} \mathrm{O}_{3}-\mathrm{Bi}_{2} \mathrm{O}_{3}$ glasses with high bismuth oxide content," Journal of Non-Crystaline Solids, vol. 303, no. 3, pp. 379-386, 2002.

[20] L. Baia, R. Stefan, J. Popp, S. Simon, and W. Kiefer, "Vibrational spectroscopy of highly iron doped $\mathrm{B}_{2} \mathrm{O}_{3}-\mathrm{Bi}_{2} \mathrm{O}_{3}$ glass systems," Journal of Non-Crystalline Solids, vol. 324, no. 1-2, pp. 109-117, 2003. 
[21] P. McMillan, "Structural studies of silicate glasses and meltsapplications and limitations of Raman spectroscopy," American Mineralogist, vol. 69, no. 7-8, pp. 622-644, 1984.

[22] M. Todea and S. Simon, "Vibrational spectroscopic study on iron doped silicabismuthate glasses and glass ceramics," Journal of Optoelectronics and Advanced Materials, vol. 9, no. 3, pp. 621-624, 2007.

[23] A. A. Kharlamov, R. M. Almeida, and J. Heo, "Vibrational spectra and structure of heavy metal oxide glasses," Journal of Non-Crystalline Solids, vol. 202, no. 3, pp. 233-240, 1996.

[24] I. Ardelean, S. Cora, and D. Rusu, "EPR and FT-IR spectroscopic studies of $\mathrm{Bi}_{2} \mathrm{O}_{3}-\mathrm{B}_{2} \mathrm{O}_{3}-\mathrm{CuO}$ glasses," Physica $B$, vol. 403, no. 19-20, pp. 3682-3685, 2008.

[25] B. J. Saikia, G. Parthasarathy, and N. C. Sarmah, "Fourier transform infrared spectroscopic estimation of crystallinity in $\mathrm{SiO}_{2}$ based rocks," Bulletin of Materials Science, vol. 31, no. 5, pp. 775-779, 2008.

[26] B. N. Meera and J. Ramakrishna, "Raman spectral studies of borate glasses," Journal of Non-Crystalline Solids, vol. 159, no. 1-2, pp. 1-21, 1993. 


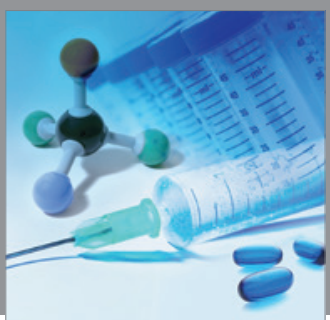

International Journal of

Medicinal Chemistry

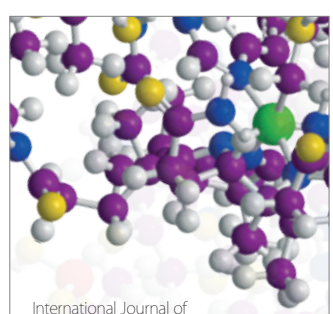

Carbohydrate Chemistry

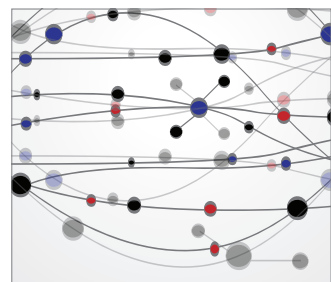

The Scientific World Journal
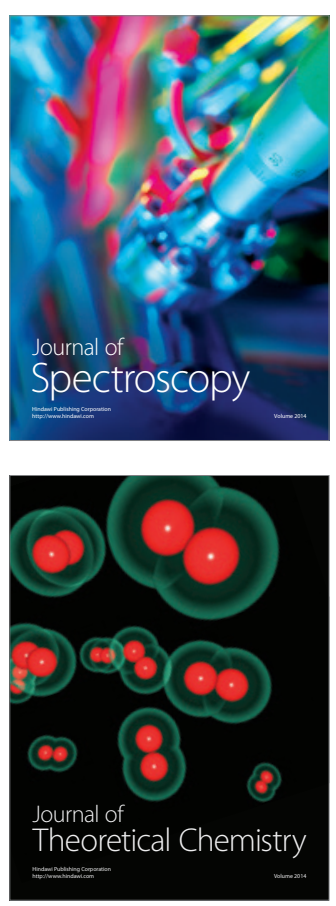
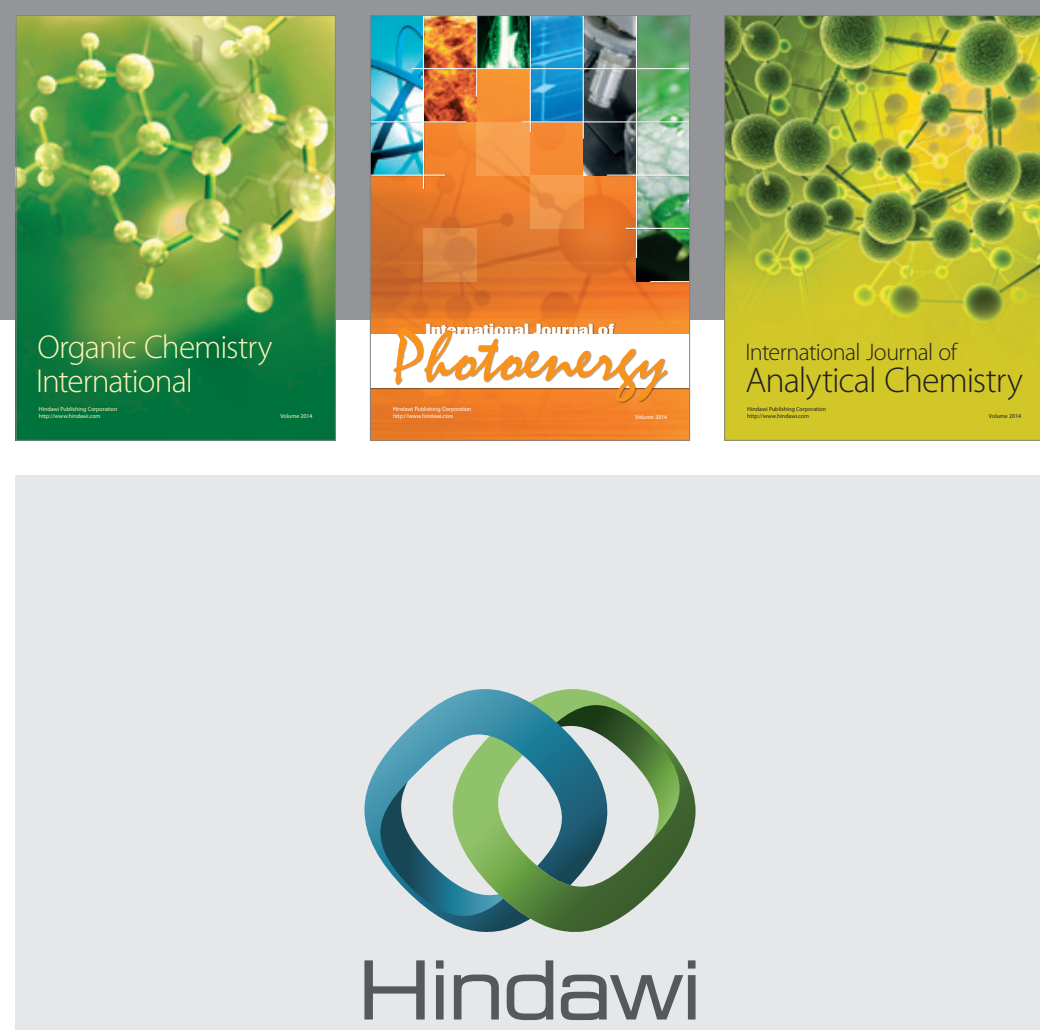

Submit your manuscripts at

http://www.hindawi.com
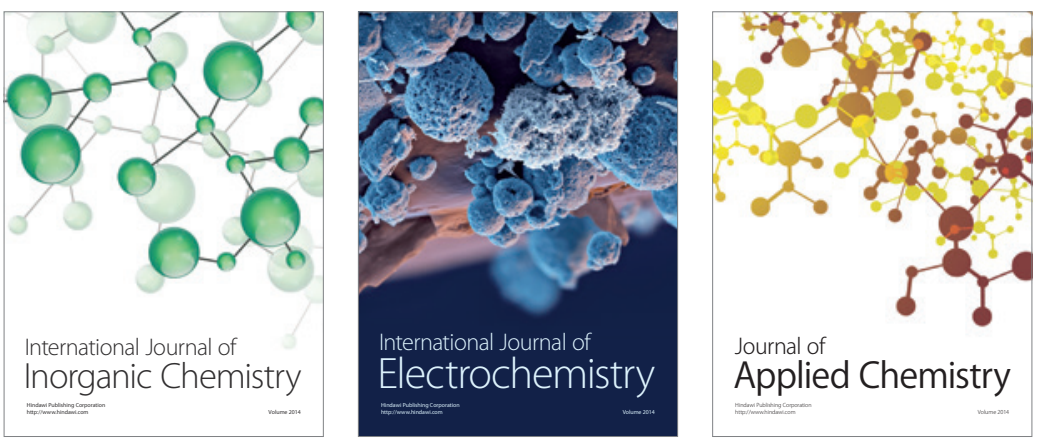

Journal of

Applied Chemistry
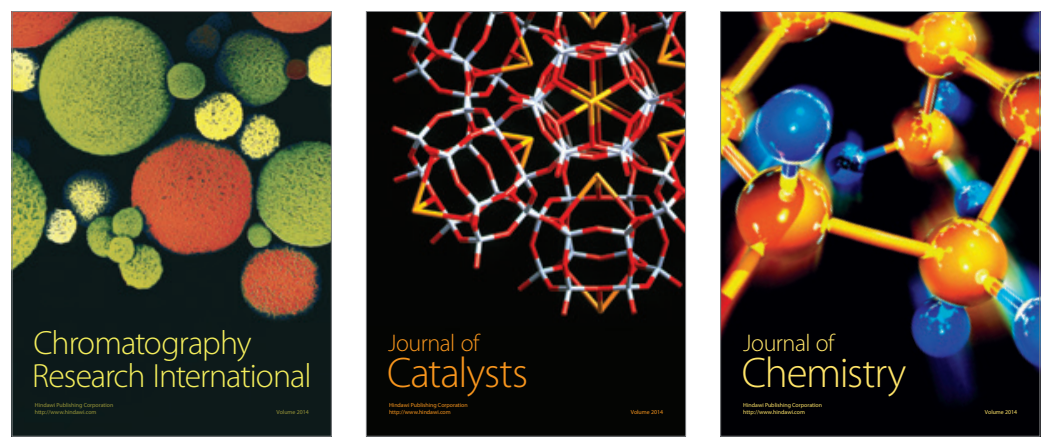
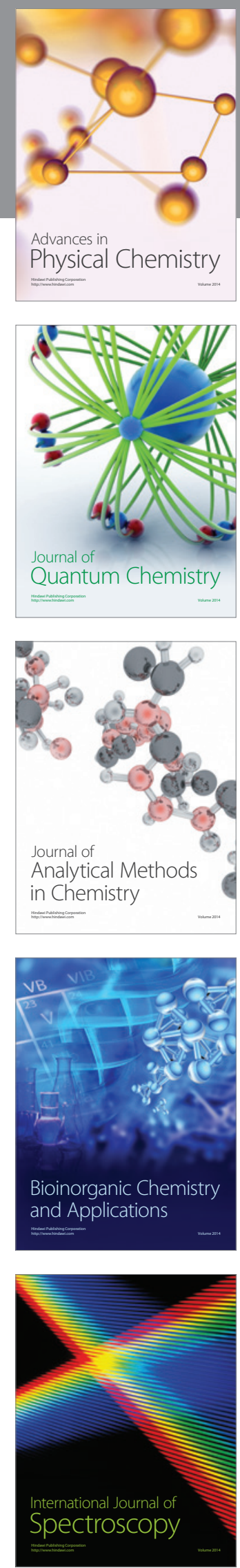